\title{
RELIGIO-CENTRIC SELLING STRATEGY IN THE RELATIONSHIP BETWEEN MARKET SENSING CAPABILITIES AND THE SMES BUSINESS PERFORMANCE
}

\author{
Hendar* \\ *Corresponding author: \\ Universitas Islam Sultan Agung (UNISSULA), Semarang, Indonesia, hendar@Unissula.ac.id
}

\begin{abstract}
This paper aims to investigate and examine the mediating role of religio-centric selling strategy in relation to market sensing capabilities with SMEs business performance in religious-based industries. This paper selected 330 Muslim SMEs in Central Java and tested the regressive relationships of the three constructs. Through confirmatory factor analysis and goodness of fit model testing using SEM, the results of market sensing capabilities obtained have a positive effect on the religio-centric selling strategy and SMEs business performance. In addition, the religio-centric selling strategy also has a positive impact on SMEs business performance. Therefore, the religio-centric selling strategy really acts as a partial mediation in relation to market sensing capabilities with SMEs business performance. By examining the literature on various marketing capabilities, selling strategies, religiosity, and SMEs business performance, this paper offers a unique analysis of the relationship between market sensing capabilities and religio-centric selling strategy and their impact on SMEs business performance. Conceptual discussions and empirical results are expected to extend previous research on the culture of market orientation and selling strategy in specific religious-based small businesses.
\end{abstract}

Keywords: Market sensing capability, religio-centric selling strategy, SMEs business performance

\section{INTRODUCTION}

This paper aims to introduce a new concept of religio-centric selling strategy in the religious-based market segment, also to examine the role of religio-centric selling strategy in the relationship between market sensing capabilities and SMEs business performance. Constructions which are the result of a synthesis of selling strategy concepts and religio-centric concepts are offered as a solution in overcoming the problem of the knowledge gap between market sensing capabilities and business performance. Considering that the market sensing capability as part of dynamic marketing capabilities, this paper is expected to contribute to the development of Resource-Based Theory (RBT) and Dynamic Capability (DC).

There are some reasons that classify this test as meaningful. First, in the last three decades, there has been a lot of research that focuses on the relationship between marketing capabilities such as market sensing capabilities and business performance. Such studies generally have shown that market sensing capabilities are a key factor that determines superior business performance (Lindblom, Olkkonen, Mitronen, \& Kajalo, 2008; Osakwe, Chovancova, \& Ogbonna, 2016). Nevertheless, some research findings still show contradictory results. While empirical findings show that market sensing capabilities are an important driver of business performance improvement (Osakwe et al., 2016), other studies show that market sensing capabilities do not have a direct impact on business performance (Ardyan, 2016; Olavarrieta \& Friedmann, 2008); and the level of income, margin and profit growth (N. A. Morgan, Slotegraaf, \& Vorhies, 2009). This difference might suggest moderators who have not 
been dealt with, defective or inappropriate measurement tools, or a variety of data collection techniques or analysis. Testing the role of religio-centric sales strategies in relation to market sensing capabilities with SMEs business performance might be the right solution so that it becomes a new reference source in development of RBT, DC, and Marketing Strategies.

Second, in addition to the research gap above, so far, researchers have not had much to determine how the capabilities of market sensing contribute to superior business performance. Several studies have investigated potential mediators from the relationship between market sensing capabilities and business performance. For example, market orientation conducted by Foley and Fahy (2004), product innovativeness success conducted by Ardyan (2016). Such research is needed to understand the routes of market sensing capabilities that affect business performance. From the perspective of strategic marketing, market sensing capabilities remain incomplete if practitioners do not understand the modus operandi that leads to superior business performance. By explaining the mediator relationship between market sensing capabilities and business performance will provide managers with more detailed insight into how to market sensing works and how it can be useful as an increase in business performance. Therefore, this study attempts to fill the knowledge gap by placing a religio-centric selling strategy as mediation in relation to market sensing capabilities and business performance.

Third, so far, there are still very few studies that investigate the role of religio-centric concepts in improving business performance, especially in SMEs. Though several studies have shown the role of religion which is very dominant in determining the behavior and buying the interest of customers (Khan \& Kirmani, 2018; Souiden \& Rani, 2015). The followers of a strong religion will tend to obey the rules and codes of ethics established by the religious doctrines adopted (Mansori, Sambasivan, \& Md-Sidin, 2015). Even members of religious groups affiliated with certain religions will consider the religiosity attributes of their religion to be perceived as better than the attributes possessed by groups that adhere to other religions (Sterkens and Anthony 2009). This should be an important source of information for business people serving religious-based market segments.

Fourth, related to the object of research, currently, Indonesia has a very large population and most of them are Muslims. In addition, dressed by covering the aurat is understood as an order of Al-Qur'an which requires simple clothing and covers their entire body (except the face and palms). This is a huge opportunity to market religious-based products, such as Muslim clothing. At this time, Muslim fashion in Indonesia have reflected the lifestyle of modern society, followed trends, were very fashionable, and fashion styles used illustrated that Indonesia was a Muslim country. The demand for Muslim clothing continues to increase, the hijab communities (community that promotes style of wearing veil) continue to grow, and the implementation of a variety of religious activities that continue to grow enables Indonesia to become the world's Muslim fashion center in 2020 (Nuraini, 2015). The reasons are that, (1) various media have displayed the appeal of Muslim fashion products that can influence consumer buying behavior, (2) the creativity of Muslim fashion designers has given rise to fashionable fashion models without leaving an element of compliance with religious norms, ( 3 ) the emergence of trendsetters whose fashion models and styles become the role model of many consumers, (4) the absence of government barriers to creating Muslim fashion designs 
as long as they do not contradict religious teachings, and (5) information technology support that makes the entrepreneurs easier to create attractive products and maneuver in the intended market segment (Hendar, Nurhayati, \& Sugiyarti, 2018; Nuraini, 2015).

\section{LITERATURE REVIEW}

\section{Religio-centric Selling Strategy}

Religio-centric selling strategy is a new construct of a combination of sales and religiocentric strategy constructs. The selling strategy is a collection of processes that companies use before selling goods and/or services for the purpose of meeting the right person, at the right time and location, by using the best techniques to affect the person (Abed \& Haghighi, 2009). There are four dimensions of the selling strategy that become a concern of the sales practitioners and researchers, namely adaptive selling strategy, customer-oriented selling strategy, sincerity, commitment: liability of salesperson's strategy, and relational selling strategy (Abed \& Haghighi, 2009).

First, adaptive selling strategy refers to the changes in sales behavior during customer interactions or cross interactions based on perceived information about the character of the sales situation (Weitz, Sujan, \& Sujan, 1986). Adaptive selling is also conceptualized as a salesperson's process of collecting information about the sales situation and using this information to develop unique sales presentations designed to meet customer needs (Spiro \& Weitz, 1990). Second, customer-oriented selling strategy develop from the concept of marketing, and a management philosophy that states that organizations must strive to meet customer needs through a series of coordinated activities that also enable the organization to achieve its objectives. Selling strategy literature explains that the main key to success in sales is the ability to build working relationships with customers where mutual support, trust, and goals are fostered occasionally. Salespeople who maintain regular contact with their customers and develop healthy business relationships based on mutual trust can increase sales productivity (Manning, Ahearne, \& Reece, 2012). The successful implementation of customer orientation requires that salespeople must have the skills and knowledge in : (a) collecting the information about customers through effective listening, (b) analyzing and understanding customer problems; and (c) adjusting their offerings to customer needs (Abed \& Haghighi, 2009). Third, sincerity and commitment: liability of salesperson's strategy, is a strategy that focuses on the key role of sales force skills as the spearhead of the company's success. Salespeople play the role of the company's personal relationship with customers. They need to have expertise in identifying consumer needs and providing solutions that help provide them (Abed \& Haghighi, 2009). Fourth, relational selling strategy is a strategy aimed at building ongoing customer relations and maintaining competitive advantage through the acquisition of intangible assets such as customer trust and commitment (R. M. Morgan \& Hunt, 1994). Through a relational selling strategy, companies can expect to get quality relationships that can be trusted, consumers get satisfaction with quality relationships, and ultimately get loyal consumers (Lai, Chou, \& Cheung, 2013). Relational selling strategy is based on interdependence between suppliers and customers, important information exchange, trust among partners and stable relationships, which allows each party to benefit from a fair return on investment. 
Sales and marketing play a coordinating role in implicit and explicit relationships between companies and customers (Hughes, Bon, \& Malshe, 2012). Interacting directly with the external market, the sales function represents the interpersonal manifestation of the marketing concept and the company's face to the customer while also functioning as the main source of market intelligence (Le Bon \& Merunka, 2006). Therefore, the customer-oriented-selling strategy approach gets the main attention of this paper. It is appropriate to assess customer-oriented constructs in a more specific long-term relationship, especially for customers in the religiousbased market segment. This is because to achieve business performance in this segment, sellers who are committed to customer orientation will be willing to spend considerable time for understanding the customer and then satisfying the customer through long-term buyer-seller relationships. The task of the company is to train salespeople to provide the right knowledge and skills in accordance with the characteristics of the customer-based market segment so that they get sufficient resources and capabilities to be more customer-oriented. A customeroriented selling strategy leads to the successful development of relationships with customers and a positive impact on sales performance(Abed \& Haghighi, 2009).

Many empirical studies have shown that religion has an important role in influencing consumer behavior (Abou-Youssef, Kortam, Abou-Aish, \& El-Bassiouny, 2015). Religion influences customers' interest in choosing halal products (Ahmad, Rahman, \& Rahman, 2015; Mukhtar \& Mohsin Butt, 2012), and green products (Khan \& Kirmani, 2018). Furthermore, El-Bassiouny (2014) argues that Muslim consumers who are described as religious and highly religious will have different consumption patterns and will tend to consume halal products and services. Therefore, it is important for organizations to investigate, understand and measure the role of religion in consumer purchasing decisions. This will enable the organization to develop products that are in accordance with the customer's religious requirements. In addition, they can reap the benefits of the strategy by integrating religious signs and symbols in their communication (Mukhtar \& Mohsin Butt, 2012).

In general, very religious people tend to internalize religious teachings in everyday life. They believe that religion guides a person to achieve life goals and defines ideals for life so that he influences personal and social life (Bakar, Lee, \& Rungie, 2013). In this context, the religio-centric concept needs to get more attention from practitioners and researchers in the religious-based market segment. The religio-centric concept is inherent in religion because it determines an identity for both individuals and groups. Analogous to the ethnocentric concept is that a combination of positive attitudes towards members of ethnic groups and negative attitudes towards members outside ethnic groups (He \& Wang, 2015; R. KAYNAK \& EKSI, 2011), religio-centric implies a combination of positive attitudes towards group members in a religion and negative attitudes towards members of other religious groups (Sterkens \& Anthony, 2008). Religio-centric people are believers who deny the truth of other religions and who hold absolute truth that leaves no room for different religious practices (Abu-Nimer, 2004). Even members of religious groups affiliated with certain religions will consider the religiosity attributes of their religion to be perceived as better than the attributes possessed by groups that adhere to other religions (R. KAYNAK \& EKSI, 2011). For example, a religio-centric customer would prefer product that is in accordance with the 
religious principles he adheres to because he believes that it becomes the most suitable for them (Hendar, Ferdinand, \& Nurhayati, 2017).

Religio-centric is an inseparable part of the customer-oriented selling strategy for products that are closely related to religious values. Customer orientation is considered a strategic orientation that reflects the company's ability to create and provide superior customer value through market intelligence processing that involves acquiring customer information; information analysis; knowledge dissemination, and coordination of response throughout the organization (Racela, 2014). In practice, the success of a customer-oriented selling strategy depends on the ownership of salespeople on six domain areas, namely, providing information to customers, understanding customer needs, meeting customer needs, creating and delivering customer value, maintaining customer satisfaction, and maintaining long-term relationships with customers (Singh \& Koshy, 2012).

The synthesis of the religio-centric concept and the customer-oriented selling strategy results in a new concept of a religio-centric selling strategy. This concept explains the integrated decision pattern of organizations that determine important choices regarding customer-oriented selling programs to create, communicate and/or convey religiosity values in various programs to meet the needs of the target market. This can be done through the proce ss of collecting, analyzing and utilizing information about customer needs for the purpose o f determining market segmentation, target markets and the design of special relationship s with customers through religious values as the foundation. In other words, a customer-oriented selling strategy is a selling strategy with a focus on, (a) fulfilling product needs for customers in religiousbased market segments; (b) development of product attributes, management o f customer information, maintenance of customer interactions, and religious-based sa les presentations; and (c) ethical sales techniques. Companies with customer-oriented selling strategies have a greater opportunity to improve business performance in the religious-based market segment.

\section{Market Sensing Capability}

Market sensing capability was introduced by Day (1994) as part of leaning market capabilities that explain the company's capacity to have a deeper insight and understanding of the market environment that is considered to have an impact on corporate customers, competitors and other strategic business partners. In other words, market sensing capabilities are the ability of companies to learn about customers, competitors, channel members, and the broader market environment in which the company operates (N. A. Morgan, Slotegraaf, et al., 2009). There are four important dimensions of market sensing capabilities related to market knowledge development, namely information acquisition activities, information dissemination activities, information interpretation activities, and information storage retrieval (Olavarrieta \& Friedmann, 2008). This capability enables companies to produce superior market knowledge, which is considered a prerequisite for any dynamic capability (Eisenhardt \& Martin, 2000).

As Foley and Fahy (2004) views about four dimensions that have special resonance in market sensing activities, namely organizational systems, marketing information, organizational communication, and learning orientation; market sensing capabilities are part of organizational learning related to strategic marketing about customers, competitors, and channel members in 
a changing market environment. Market sensing capabilities can be unique capabilities that are key to opening up current and future market opportunities (Osakwe et al., 2016). Day (1994) emphasizes the need for companies to develop the necessary knowledge with specific skills relevant to understanding changing business dynamics in certain industries or market segments. Companies with market sensing capabilities are aimed at their ability to learn about customer needs and requirements, discover competitors' strategies and tactics, gain insight into channels, identify and understand market trends, and learn about a broad market environment.

\section{Market Sensing Capability and Religio-centric Selling Strategy}

Marketing literature hopes that superior market sensing capabilities will lead to selling strategies. This is because of some reasons: First, market sensing capability is one component of marketing capability that provides valuable customer information to create quality marketing strategies and its implementation (N. A. Morgan, 2012). A salesperson who has complete and accurate product knowledge will be better able to identify and satisfy customer needs. Additional benefits can be obtained from comprehensive product knowledge including greater self-confidence, increased enthusiasm, increased ability to develop stronger sales appeal, and increased ability to overcome objections (Manning et al., 2012). Second, aspects of customer intelligence from market sensing capability provide insight for managers about opportunities in the customer base to make strategic marketing decision and its implementation, including in the selling strategy. Sales intelligence is needed when sales are complex and requires a long closing cycle. Sales intelligence provides insight into salespeople about market access, company position, and competitor strategies. Sales intelligence is needed now because of the prospect of seeking insight and knowledge from salespeople about product features and benefits (Manning et al., 2012). Thus, superior market sensing capabilities enable companies to learn more and faster about customer and competitor reactions in improving the past business performance, thus providing the insights needed to design the right selling strategy in the future.

In the religious-based market segment, the quality of the selling strategy is highly dependent on information changes in customer needs that are in line with religious values. For example, Ahmed Zebal and M. Saber (2014) point to the importance of the orientation of the Islamic market to market religious-based products. The orientation meant consists of orientation to Islamic customers, orientation to information, orientation to integration, orientation to competition, and orientation to responsiveness that contributes to the formation of Islamic market orientation. Information obtained from market intelligence in these market segments will be a valuable resource in making strategic marketing decision and its implementation, including religio-centric selling strategy. Therefore, the $\mathrm{H} 1$ hypothesis is set as follows:

H1 : There is a positive relationship between market sensing capability and a religio-centric selling strategy

\section{Market Sensing Capability and Business Performance}

The strategic marketing literature hopes that market sensing capabilities can be linked to marketing performance. This is for several reasons. First, market-oriented culture and ownership of market sensing skills are needed to develop and foster innovation and imitation capabilities 
in an organization (Olavarrieta \& Friedmann, 2008). Second, superior market sensing capability enables companies to identify underserved segments so that they provide a good target for the company's efforts to increase revenue by attracting new customers (N. A. Morgan, Slotegraaf, et al., 2009). Third, aspects of customer intelligence from market sensing capability provide managers with insight into opportunities in the existing customer base to expand the share that companies can exploit (N. A. Morgan, Anderson, \& Mittal, 2005). Fourth, superior market sensing capability provides market insights that enable companies to lower their average costs through more productive use of resources by better matching the acquisition and deployment of company resources with customer opportunities and prospects (N. A. Morgan, Vorhies, \& Mason, 2009). Fifth, companies with strong market-sensing capability will be better able to identify the most pricesensitive customers and prospects so that they will be able to charge higher prices. Sixth, superior market sensing enables companies to learn more and learn more quickly about the reactions of customers and competitors to efforts to increase revenue and margin growth in the past, provide the insights needed to enable companies to increase the level of achievement of these growth outcomes (N. A. Morgan, Slotegraaf, et al., 2009). Therefore, hypothesis 2 is proposed as follows: $H 2$ : There is a positive effect between market sensing capability and business performance.

\section{Religio-centric Selling Strategy and Business Performance}

Strategy marketing literature has explained the effectiveness of marketing strategies that always leads to marketing performance. For example, first, on the international market, N. A. Morgan, Katsikeas, and Vorhies (2012)show that an effective implementation of export marketing strategy will determine market performance and financial performance. Second, Hasan and Ali (2015)found that in the green product market, the marketing strategy and innovation of green products had a positive impact on the performance of companies in Malaysia. Third, adaptive selling strategy and customer-oriented selling strategy lead to increased sales force performance (E. Kaynak, Kara, Chow, \& Laukkanen, 2016). Fourth, the selling strategy explained through a combination of sales management, customer priorities, and market segmentation models is an important driver of market performance and sales force performance (Terho, Eggert, Haas, \& Ulaga, 2015).

Some of the information shows that marketing strategies and selling strategies (as an important part of marketing strategies) have a very significant role in improving business performance. In this context, it is very possible that the religio-centric selling strategy also leads to business performance. The religio-centric selling strategy is related to decisions and implementation of selling strategies regarding commitment to meeting customer needs in religious-based market segments, focusing on developing religious-based product attributes, oriented to religious-based customer information management, oriented towards maintaining religious-based customer interactions, unique religious-based sales, and ethics-based sales techniques. Such companies that have the characteristics of a selling strategy will produce a positive impression and attractiveness of the customer towards the product and its sales force, increasing customer buying interest, so that it will ultimately improve the company's marketing performance. Therefore, hypothesis 3 is set as follows:

H3: Religio-centric selling strategy positively affects the company's marketing performance 


\section{The Mediation Role of Religio-centric Selling Strategies}

In a dynamic environment, increasing market sensing capabilities will create and enhance the capabilities needed for future success. This is for two reasons, (a) they are better able to understand the strengths and weaknesses of competitors, and they learn from the successes and failures of competitors, and (b) they use this knowledge to understand and anticipate customer needs (Calantone, Cavusgila, \& Zhao, 2002). In this context, market sensing capabilities facilitate valuable market information to design selling strategy decision and its implementation.

Meanwhile, in some empirical studies, the selling strategy is also based on business performance. For example, Terho et al. (2015) find a selling strategy that has a positive impact on market performance. Abed and Haghighi (2009) found that adaptive and relational selling strategies had a positive relationship with sales performance. The significance of similar findings is very likely to occur in religious-based SMEs, meaning that the religio-centric selling strategy has considerable potential in improving SMEs business performance.

The positive effect of market sensing capabilities on selling strategies and the positive effect of selling strategies on business performance show that the selling strategy has an important role as mediation in the relationship between market sensing capabilities and business performance. In the scope of the religious-based market segment, the opportunity for such a relationship is very possible. This means that the religio-centric selling strategy has an important role as mediation in the relationship between market sensing capabilities and business performance. Therefore, the $\mathrm{H} 4$ hypothesis is proposed as follows:

H4 : Religio-centric selling strategy acts as a mediation in the relationship between market sensing capabilities and SMEs business performance.

\section{RESEARCH METHOD Sample and Procedure}

The population of this study are owners, managers or owners who are also managers of Muslim fashion small businesses in Indonesia, namely those who have a net worth of at most 500,000,000 or who have annual sales of at most Rp 2,500,000,000 (RI Law No. 20 of 2008 ). The data used were 330 respondents obtained from distributed questionnaires to 450 respondents in 10 districts/cities in Central Java, Indonesia (around 73.30\%). Respondents are selected from small businesses that have at least 3 years of experience. The questionnaire will be distributed by officers who have been trained in advance to the small business owner or manager of the small business. Because factually the population is not known with certainty, the sampling method is done trough a non-probability sampling with a snowball sampling technique. Through this method, sampling is done by tracing one respondentto the other respondents. Characteristics of respondents obtained are shown in Table 1. 
Table 1: Characteristics of respondents based on gender, position in the company, age, family background, education level and marital status

\begin{tabular}{|c|c|c|c|c|}
\hline No & $\begin{array}{l}\text { Characteristics of } \\
\text { respondent }\end{array}$ & Dimension & Total & Percentage \\
\hline \multirow{3}{*}{1} & \multirow{3}{*}{ Gender } & Female & 284 & 86,00 \\
\hline & & Male & 46 & 14,00 \\
\hline & & Total & 330 & 100.0 \\
\hline \multirow{4}{*}{2} & \multirow{4}{*}{ Position in the company } & Owner & 99 & 30,00 \\
\hline & & Manager & 89 & 27,00 \\
\hline & & Owner and manager & 142 & 43,00 \\
\hline & & Total & 330 & 100.0 \\
\hline \multirow{7}{*}{3} & \multirow{7}{*}{ Age } & under 26 years & 131 & 39,70 \\
\hline & & 26 to 30 years & 62 & 18,80 \\
\hline & & 31 to 35 years & 60 & 28,20 \\
\hline & & 36 to 40 years & 28 & 8,50 \\
\hline & & 41 to 45 years & 32 & 0,97 \\
\hline & & Over 45 years & 17 & 0,05 \\
\hline & & Total & 330 & 100.0 \\
\hline \multirow{6}{*}{4} & \multirow{6}{*}{ Level of education } & Elementary school and junior high school level & 15 & 4,50 \\
\hline & & Senior high school level & 198 & 60,00 \\
\hline & & Associate Degree & 22 & 6,67 \\
\hline & & Bachelor Degree & 93 & 28,18 \\
\hline & & Master Degree & 2 & 0,60 \\
\hline & & Total & 330 & 100.0 \\
\hline
\end{tabular}

Source: Primary data processed, 2018

\section{Instrument}

Two exogenous variables are used in this study, namely, marketing capability and market sensing capabilities. Market sensing capabilities were adapted from N. A. Morgan, Slotegraaf, et al. (2009) and Lindblom et al. (2008). Market sensing capability is the ability of companies to learn about customer needs and desires, discover competitors' strategies and tactics, gain insight into channel members, identify and understand market trends, and learn about a broad market environment. An intervening variable, namely the religio-centric selling strategy is a new variable formed from the collaboration concept of the selling strategy and religio-centric based on the view of Hendar et al. (2017). Religio-centric selling strategy is an integrated decision pattern of organizations that determines important choices regarding customer-oriented selling programs to create, communicate and/or convey values of religiosity in various programs meeting the needs of the target market. Meanwhile, business performance as a consequence variable was adapted from the view of Soliman (2011), Merrilees, RundleThiele, and Lye (2011) and Healy, Ledwith, and O'Dwyer (2014), namely a combination of the results of marketing activities that are perceived by the owner or manager of the company about achieving sales growth, increasing sales volume, achieving sales targets, customer growth and expanding marketing areas. 
Each of the five instruments is used to measure the construct of market sensing capabilities and MSMEs business performance, and 6 instruments to measure religio-centric selling strategies. By measuring each instrument using an interval scale of 1 to 10 , a score of 1 indicates strongly disagree with a statement submitted and a score of 10 indicates strongly agree (Ferdinand, 2014). The instruments of each variable are explained in Table 2.

\section{Analysis Techniques}

Structural equation model (SEM) is used to test empirical research models. The Confirmatory Factor Analysis Model is used to test the multidimensionality of a theoretical construct. In addition, SEM is also used as a comprehensive test tool for full structural models. Data analysis follows the process recommended by Hair, Black, Babin, and Anderson (2010). First, make a path diagram model of causality between constructs and indicators. Second, test the unidimensional of each construct with confirmatory factor analysis. Third, estimate the full structural model equation for indicators that have passed the confirmatory test. Fourth, discuss convergence and discriminant validity before moving to substantive analysis. SEM analysis was carried out using Amos software version 22.00.

\section{RESULTS}

This paper reports the results of confirmatory factor analysis for a complete sample as outlined in Table 2. Tests were carried out on 16 instruments ( 5 market sensing capability instruments, 6 religio-centric selling strategy instruments, and 5 MSMEs business performance instruments) to obtain 16 loading factor values $(\lambda 1-\lambda 16)$ that is relevant. Unidimensional assessment is done by examining the maximum likel $\mathrm{i}$ hood estimates factor loading, which exceeds 0.6 (Hair et al., 2010). In accordance with the provisions in AMOS, the loading factor for all observed latent variables has good validity because it has a value above 0.6 (Table 2).

High construct reliability indicates internal consistency, which means that indicators consistently represent the same latent construct (Hair et al., 2010). Construct reliability (CR) that exceeds 0.7 , variance extracted (VE) that exceeds 0.5 and discriminant validity (DV) that is greater than 0.7 is a standard of internal consistency measurement of the instruments used. Table 3 shows CR values greater than 0.7; VE that exceeds 0.5, AVE squared that exceeds the correlation value between variables for market sensing capabilities, the religio-centric selling strategy, and MSMEs business performance shows that each instrument has good validity in explaining the research variables used.

Table 2:Instruments and Confirmatory Factor Analysis Results for the Measurement Model ${ }^{\text {a) }}$

\begin{tabular}{|l|c|}
\hline \multicolumn{1}{|c|}{ Market Sensing Capability (KPP) } & p-value \\
\hline Ability to learn about customer needs and desires (KPP1) & $0.703^{* *}$ \\
\hline Ability to learn and understand the strategies and tactics of the company's main competitors (KPP2) & $0.688^{* *}$ \\
\hline Ability to get information about members of the distribution and communication channel (KPP3) & $0.712^{* *}$ \\
\hline Ability to identify and understand market trends (KPP4) & $0.706^{* *}$ \\
\hline The ability to learn to understand a changing market environment (KPP5) & $0.714^{* *}$ \\
\hline \multicolumn{2}{|c|}{ Religio-centric Selling Strategy (SPR) } \\
\hline
\end{tabular}




\begin{tabular}{|c|c|}
\hline Commitment to meeting customer needs in the religious-based market segment (SPR1) & $0.731^{* *}$ \\
\hline Focus on developing religious-based product attributes (SPR2) & $0.679 * *$ \\
\hline Oriented to managing religious-based customer information (SPR3) & $0.695 * *$ \\
\hline Oriented to religious-based customer interaction maintenance (SPR4) & $0.750^{* *}$ \\
\hline Unique religious-based sales presentation (SPR5) & $0.746 * *$ \\
\hline Ethical-based sales techniques (SPR6) & $0.723^{* *}$ \\
\hline \multicolumn{2}{|l|}{ MSMEs Business Performance (KBU) } \\
\hline Increased sales (rupiah) for the last 3 years (KBU1) & $0.687 * *$ \\
\hline Increase in sales volume (units) in the last 3 years (KBU2) & $0.658 * *$ \\
\hline Customer growth for the last 3 years (KBU3) & $0.711 * *$ \\
\hline Expansion of sales area for the last 3 years (KBU4) & $0.667 * *$ \\
\hline Profit growth over the past 3 years (KBU5) & $0.704 * *$ \\
\hline $\begin{array}{l}{ }^{\mathrm{a}} \mathrm{X}^{2}=123.077 ; \mathrm{DF}=101, \text { probability }=0.067, \mathrm{GFI}=0.956, \mathrm{AGFI}=0.943, \mathrm{TLI}=0.987, \mathrm{CFI}=0.989, \\
\text { RMSEA }=0.026, \mathrm{CMIM} / \mathrm{DF}=1.219, \text { Hoetler01 }=367 \\
*) \text {-value } \leq 0.05 * *), \mathrm{p} \text {-value } \leq 0.01\end{array}$ & \\
\hline
\end{tabular}

Table 3: Construct Reliability, Correlation and AVE

\begin{tabular}{lccc}
\hline \multicolumn{1}{c}{$\mathrm{N}=330$} & 1 & 2 & 3 \\
\hline 1. Market Sensing Capability (KPP) & $\mathbf{0 . 8 3 1}^{\text {a) }}$ & & \\
2. Religio-centric Selling Strategy (SPR) & 0.405 & $\mathbf{0 . 8 6 7}$ & \\
3. MSMEs Business Performance (KBU) & 0.492 & 0.472 & $\mathbf{0 . 8 2 4}$ \\
\hline Average Variance Extracted (AVE) & 0.843 & 0.879 & 0.833 \\
\hline
\end{tabular}

a) The construct reliability factor is in diagonal (the bold one).

The results of testing the full structural equation model show a good Good-of-Fit index because it produces criteria in accordance with the recommended SEM. The value of $\mathrm{X}^{2} 123,077$ with $\mathrm{p}$-value $=0.067$ which is not significant at $\alpha 0.05$, GFI index 0.956 , AGFI 0.943, TLI 0.987, CFI 0.989 which exceeds 0.90 and other criteria such as RMSEA 0.026 which is less than $0.08, \mathrm{CMIM} / \mathrm{DF}=1.219$ which is less than 2 , and the value of Hoetler01 $=367$ which exceeds the number of samples (330) has met the recommended criteria in SEM (Table 2). This shows the recommended model is fit or has the feasibility to test the relationship among variables.

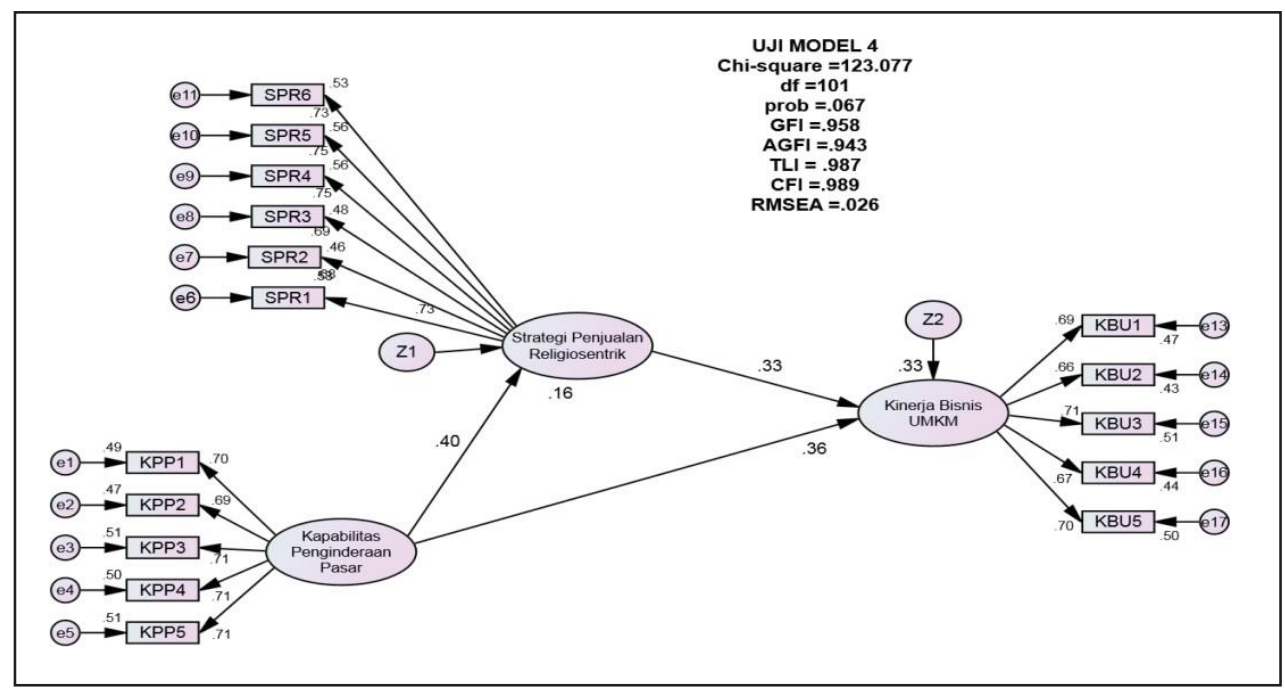


Table 4 and Figure 1 show the results of direct effects, that is a significant positive effect between market sensing capabilities and religio-centric selling strategies ( $\operatorname{Std} \beta=0.407$, cr $=5,896, p$-value $<0.01)$, market sensing capabilities of SMEs business performance (Std $\beta$ $=0.325, \mathrm{cr}=4.715, \mathrm{p}$-value $<0.01$ ), and the religio-centric selling strategy for SMEs business performance $(\operatorname{Std} \beta=0.293$, $\mathrm{cr}=4.925$, $\mathrm{p}$-value $<0.01$ ). This shows that the hypotheses $\mathrm{H} 1$, $\mathrm{H} 2$, and $\mathrm{H} 3$ are accepted.

Table 4. Parameter estimates for the path: direct effects

\begin{tabular}{clrrrrl}
\hline Hyp. & \multicolumn{1}{c}{ Regression } & Std B & Unstd B & \multicolumn{1}{c}{ S.E. } & C.R. & Note \\
\hline H1 & KPP $\rightarrow$ SPR & 0.407 & 0.405 & 0.069 & $5.896^{* *}$ & Accepted \\
H2 & KPP $\rightarrow$ KBU & 0.325 & 0.326 & 0.066 & $4.715^{* *}$ & Accepted \\
H3 & SPR $\rightarrow$ KBU & 0.293 & 0.360 & 0.062 & $4.925^{* *}$ & Accepted \\
H4 & KPP $\rightarrow$ SPR $\rightarrow$ KBU & 0.119 & 0.146 & 0.033 & $3.680^{* *}$ & Accepted \\
\hline
\end{tabular}

Note: $* \mathrm{p}<0.05 ; * * \mathrm{p}<0.01$

Regarding H4, testing the mediating role of religio-centric selling strategy in the relationship between market sensing capabilities and SMEs business performance, this paper used the Sobel test uploaded online through the site http://quantpsy.org/sobel/sobel.htm. The direct effect of market sensing capability on religio-centric selling strategy is explained by Unstd $\beta 0.405$, S.E 0.069 and c.r 5,896 so that it is significant at $\alpha 0.01$. The direct effect of the religio-centric selling strategy on SMEs business performance is explained by Unstd $\beta 0.360$, S.E 0.062 and c.r 4.925 so that it is significant at $\alpha 0.01$. The indirect effects of market sensing capabilities on the SMEs business performance through religio-centric selling strategies are explained by the coefficient of Unstd $\beta 0.146(0.405 \times 0.360)$. The Sobel Test results show the value of c.r 3.680, S.E 0.033 and p-value 0.0002 so that it is significant at $\alpha$ 0.01 . The total effect of market sensing capabilities on MSMEs business performance is Unstd $\beta 0.472(0.326+0.146)$ which is greater than direct effects $(0.326)$, this shows that religiocentric selling strategy has a very important role as partial mediation in relation to market sensing capabilities with MSMEs business performance and becomes an important alternative in improving MSMEs business performance. Therefore, this study accepts the H4 hypothesis.

\section{DISCUSSION}

As explained above, the purpose of this paper is to introduce a new concept of religiocentric selling strategy and simultaneously test the role of constructive mediation in the relationship between market sensing capabilities and the SMEs businesses performance in the segment of religious-based markets. Several religio-centric selling strategy instruments have been proposed and tested their validity and reliability. The results are really encouraging because all the instruments used are very valid and reliable. These results also show six (6) characteristics of companies that have a strong religio-centric selling strategy, namely: (a) have a commitment to meeting customer needs in the religious-based market segment, (b) always focus on developing religious-based product attributes, ( c) oriented to the management of religious-based customer information, (d) oriented to the maintenance of 
religious-based customer interactions, (e) used to conducting unique religious-based sales presentations, and (f) using ethical-based sales techniques. SMEs with the characteristics of such sales strategies are likely to produce better business performance. This is evidenced by the results of empirical testing which shows that there is a significant effect of the religiocentric selling strategy on SMEs business performance. This relationship is very possible for several reasons:

1. Religion has a dominant role in consumer purchasing decisions (Ahmad et al., 2015; Souiden \& Rani, 2015). The commitment of SMEs to meet customer needs by continuing to develop product attributes and religious-based services will increase the attractiveness of products and customers' buying interest.

2. Market information is a source of strategic decisions for company (N. A. Morgan, 2012). In the religious-based market segment, SMEs who have information related to customer religiosity will be more adaptable in selling their products.

3. The ability to build customer relationships is the key to success in business (Y. Wang \& Feng, 2012; Z. Wang \& Kim, 2017). This relationship can be developed through customer interaction patterns based on religious values. Emotional attachments in religious affiliation will create love and commitment to these religious groups, including the products offered.

4. The quality of sales presentations leads to the salespeople performance (Joh lke, 2006). Internalizing religious values in sales presentations will increase customer trust because this is directly related to human closeness to God.

5. Selling strategy literature ex plains sales techniques using ethics are needed to build customer trust. Some personal business ethics codes such as sales must be seen as an exchange of values, prioritizing relationships and being honest to self and others becomes part of that belief (Manning et al., 2012). Trust will have a positive impact on customer satisfaction and loyalty (Martínez \& Rodríguez del Bosque, 2013).

This research has also proven how important the role of religio-centric selling strategy in improving the performance of religious-based SMEs businesses, such as Muslim fashion. The fashion industry is very dynamic, has short life cycle characteristics, unstable demand, low predictability and a high level of impulse buying (Christopher, Lowson, \& Peck, 2004). In industries with such characteristics, most companies make strategic decisions by offering unique product variations or competitive pricing (Ahmadi, O'Cass, \& Miles, 2013). The religio-centric selling strategy approach is one alternative that should be considered.

The existence of a good positive influence between market sensing capability and the religio-centric selling strategy and the significant influence between the religio-centric selling 
strategy and the SMEs business performance show that the religio-centric selling strategy actually plays a role as partial mediation in relation to market sensing capabilities with SMEs business performance. The role of partial mediation meant occurs because there is a significant direct relationship between market sensing capability and SMEs business performance. The findings of the religio-centric selling strategy as a partial mediation in various relationships indicate that the strategy has a strategic role in delivering market sensing capability to better SMEs business performance. The total effect of a direct and indirect relationship will be greater than the direct effect. According to Rucker et. al. (2011), the mediation of religio-centric selling strategies will strengthen the relationship of professional market sensing capabilities in improving business performance. This shows that the religio-centric selling strategy has become a convincing mediator in relation to market sensing capabilities and the SMEs business performance.

\section{CONCLUSION}

The existence of a clear relationship between the three constructs, namely market sensing capabilities, religio-centric selling strategies and the SMEs business performance show the mediating role of religio-centric selling strategies in relation to market sensing capabilities and business performance. This is in accordance with what is expected by Resource-Based Theory and Dynamic Capability Theory, namely the ownership of superior marketing capabilities (such as market sensing capabilities) will make the companies easier to develop marketing strategies that lead to the creation of competitive advantage and increased business performance. Thus, these findings contribute to the development of Resource-Based Theory and Dynamic Capability Theory. For SMEs practitioners, these findings suggest the importance of increasing market sensing capabilities to be considered in making selling strategy decisions. Information that is obtained from market intelligence is very valuable for making the right decisions in accordance with the interests of customers.

\section{Limitation and Future Research Direction}

This paper only explains the role of one component of marketing capabilities, namely market sensing capabilities on religio-centric selling strategies and business performance. While there are still many dimensions of marketing capability that have not been considered, such as marketing architectural capabilities, the capabilities of marketing specialists, the capability of developing new products, and the capability of managing brands as suggested by N. A. Morgan (2012). Empirical testing of the individual relationships of constructs of marketing capabilities with religio-centric selling strategies still needs to be done. In addition, a relationship model of various constructs of marketing capabilities with a more complex religio-centric selling strategy and business performance can be done to produce more comprehensive findings. Interesting studies on such cases will be very valuable for the development of Resource-Based Theory, Dynamic Capability Theory and Marketing Dynamic Capability in religious-based markets. 


\section{REFERENCES}

Abed, Ghazaleh Moghareh, \& Haghighi, Mohammad. (2009). The effect of selling strategies on sales performance BUSINESS STRATEGY SERIES, 10(5), 266-282.

Abou-Youssef, Mariam Mourad Hussein, Kortam, Wael, Abou-Aish, Ehab, \& El-Bassiouny, Noha. (2015). Effects of religiosity on consumer attitudes toward Islamic banking in Egypt. International Journal of Bank Marketing, 33(6), 786-807. doi: 10.1108/ijbm02-2015-0024

Abu-Nimer, Mohammed. (2004). Religion, Dialogue, and Non-Violent Actions in PalestinianIsraeli Conflict. International Journal of Politics, Culture and Society, Vol. 17(No. 3), pp. 491-511.

Ahmad, Ahlam Nuwairah, Rahman, Azmawani Abd, \& Rahman, Suhaimi Ab. (2015). Assessing Knowledge and Religiosity on Consumer Behavior towards Halal Food and Cosmetic Products. International Journal of Social Science and Humanity, 5(1), 10-14. doi: $10.7763 /$ ijssh.2015.v5.413

Ahmadi, Hormoz, O'Cass, Aron, \& Miles, Morgan P. (2013). Product resource-capability complementarity, integration mechanisms, and first product advantage. Journal of Business Research. doi: 10.1016/j.jbusres.2013.11.031

Ahmed Zebal, Mostaque, \& M. Saber, Hussein. (2014). Market orientation in Islamic banks - a qualitative approach. Marketing Intelligence \& Planning, 32(4), 495-527. doi: 10.1108/ mip-08-2013-0138

Ardyan, Elia. (2016). Market Sensing Capability and SMEs Performance: The Mediating Role of Product Innovativeness Success. DLSU Business \& Economics Review, Vol. 25(No. 2), pp. 79-97.

Bakar, Abou, Lee, Richard, \& Rungie, Cam. (2013). The effects of religious symbols in product packaging on Muslim consumer responses. Australasian Marketing Journal (AMJ), 21(3), 198-204. doi: 10.1016/j.ausmj.2013.07.002

Calantone, Roger J., Cavusgila, S. Tamer, \& Zhao, Yushan. (2002). Learning orientation, firm innovation capability, and firm performance. Industrial Marketing Management, Vol. 31 , pp. 515-524.

Christopher, Martin, Lowson, Robert, \& Peck, Helen. (2004). Creating agile supply chains in the fashion industry. International Journal of Retail \& Distribution Management, 32(8), 367-376. doi: 10.1108/09590550410546188

Day, George S. (1994). The Capabilities of Market-Driven Organizations. Journal of Marketing, Vo. 5(No. 4 (Oct. 1994)), pp. 37-52.

Eisenhardt, Kathleen M., \& Martin, Jeffrey A. (2000). DYNAMIC CAPABILITIES: WHAT ARE THEY ? Strategic Management Journal, Vol. 21, pp. 1105-1121. 
El-Bassiouny, Noha. (2014). The one-billion-plus marginalization: Toward a scholarly understanding of Islamic consumers. Journal of Business Research, 67(2), 42-49. doi: 10.1016/j.jbusres.2013.03.010

Ferdinand, Augusty. (2014). Metode penelitian anajemen : Pedoman penelitian untuk penulisan skripsi, tesis dan disertasi ilmu manajemen - Management Research Method: a research guidance for writing thesis and dissertation in management science (Vol. 5). Semarang: Undip Press - Badan Penerbitan Undip.

Foley, Anthony, \& Fahy, John. (2004). Towards a further understanding of the development of market orientation in the firm: a conceptual framework based on the marketsensing capability. Journal of Strategic Marketing, 12(4), 219-230. doi: $10.1080 / 0965254042000308048$

Hair, Joseph F., Black, William C., Babin, Barry J., \& Anderson, Rolph E. (2010). Multivariate Data Analysis (Seventh Edition). Pearson Prentice Hall. New Jersey, USA. , Paper, 816 pp (ISBN-13: 9780138132637).

Hasan, Zuhairah, \& Ali, Noor Azman. (2015). The Impact of Green Marketing Strategy on the Firm's Performance in Malaysia. Procedia - Social and Behavioral Sciences, 172, 463470. doi: 10.1016/j.sbspro.2015.01.382

He, Jiaxun, \& Wang, Cheng Lu. (2015). Cultural identity and consumer ethnocentrism impacts on preference and purchase of domestic versus import brands: An empirical study in China. Journal of Business Research, 68(6), 1225-1233. doi: 10.1016/j. jbusres.2014.11.017

Healy, Brian, Ledwith, Ann, \& O’Dwyer, Michele. (2014). Perceptions of product advantage, NPD and organisational performance. Journal of Small Business and Enterprise Development, Vol. 21(No. 1), pp. 49-69. doi: 10.1108/JSBED-05-2013-0078

Hendar, Hendar, Ferdinand, Augusti Tae, \& Nurhayati, Tatiek. (2017). Introducing the religiocentric positional advantage to Indonesian small businesses. Management \& Marketing, 12(1). doi: 10.1515/mmcks-2017-0006

Hendar, Hendar, Nurhayati, Tatiek, \& Sugiyarti, Gita. (2018). Religio-centric fashion advantage on marketing performance: the role of innovativeness and customer responsiveness. Contaduría y Administración, 63(4), 60. doi: 10.22201/fca.24488410e.2018.1378

Hughes, Douglas E., Bon, Joël Le, \& Malshe, Avinash. (2012). The Marketing-Sales Interface at the Interface: Creat ing Market-Based Capabilities through Organizat ional Synergy Journal of Personal Selling \& Sales Management, XXXII(1), 57-72.

Johlke, Mark C. (2006). Sales presentation skills and salesperson job performance Journal of Business \& Industrial Marketing, 21(5), 311-319.

Kaynak, Erdener, Kara, Ali, Chow, Clement S. F., \& Laukkanen, Tommi. (2016). Role of Adaptive Selling and Customer Orientation on Salesperson Performance: Evidence from Two Distinct Markets of Europe and Asia. Journal of Transnational Management 21(2), 62-83. 
KAYNAK, Ramazan, \& EKSI, Sevgi. (2011). Ethnocentrism, Religiosity, Environmental and Health Consciousness: Motivators for Anti-Consumers Eurasian Journal of Business and Economics, Vol. 4(No. 8), pp. 31-50.

Khan, Mohammed Naved, \& Kirmani, Mohd Danish. (2018). Role of religiosity in purchase of green products by Muslim students. Journal of Islamic Marketing, 9(3), 504-526. doi: 10.1108/jima-04-2017-0036

Lai, Ming-Cheng, Chou, Feng-Sha, \& Cheung, Yu-Jen. (2013). Investigating Relational Selling Behaviors, Relationship Quality, and Customer Loyalty in the Medical Device Industry in Taiwan. International Journal of Business and Information, 8(1), 137-149.

Le Bon, Joël, \& Merunka, Dwight. (2006). The impact of individual and managerial factors on salespeople's contribution to marketing intelligence activities. International Journal of Research in Marketing, 23(4), 395-408. doi: http://dx.doi.org/10.1016/j. ijresmar.2006.10.002

Lindblom, Arto Tapio, Olkkonen, Rami Mikael, Mitronen, Lasse, \& Kajalo, Sami. (2008). Market-Sensing Capability and Business Performance of Retail Entrepreneurs. Contemporary Management Research, 4(3), 17.

Manning, Gerald L., Ahearne, Michael, \& Reece, Barry L. (2012). Selling Today : Creating Customer Value. 12th Edition. Pearson Education, Inc., publishing as Prentice Hall, One Lake Street, Upper Saddle River, New Jersey.

Mansori, Shaheen, Sambasivan, Murali, \& Md-Sidin, Samsinar. (2015). Acceptance of novel products: the role of religiosity, ethnicity and values. Marketing Intelligence \& Planning, 33(1), 39-66. doi: 10.1108/MIP-03-2013-0050

Martínez, Patricia, \& Rodríguez del Bosque, Ignacio. (2013). CSR and customer loyalty: The roles of trust, customer identification with the company and satisfaction. International Journal of Hospitality Management, 35, 89-99. doi: 10.1016/j.ijhm.2013.05.009

Merrilees, Bill, Rundle-Thiele, Sharyn, \& Lye, Ashley. (2011). Marketing capabilities: Antecedents and implications for B2B SME performance. Industrial Marketing Management, 40 (2011) 368-375. doi: 10.1016/j.indmarman.2010.08.005

Morgan, Neil A. (2012). Marketing and business performance. Journal of the Academy of Marketing Science, 40(1), 102-119. doi: 10.1007/s11747-011-0279-9

Morgan, Neil A., Anderson, Eugene W., \& Mittal, Vikas. (2005). Understanding Firms' Customer Satisfaction Information Usage. Journal of Marketing, 69(3), 131-151. doi: 10.1509/jmkg.69.3.131.66359

Morgan, Neil A., Katsikeas, Constantine S., \& Vorhies, Douglas W. (2012). Export marketing strategy implementation, export marketing capabilities, and export venture performance. Journal of the Academy of Marketing Science, 40(2), 271-289. doi: 10.1007/s11747011-0275-0 
Morgan, Neil A., Slotegraaf, Rebecca J., \& Vorhies, Douglas W. (2009). Linking marketing capabilities with profit growth. International Journal of Research in Marketing, 26(4), 284-293. doi: 10.1016/j.ijresmar.2009.06.005

Morgan, Neil A., Vorhies, Douglas W., \& Mason, Charlotte H. (2009). Market orientation, marketing capabilities, and firm performance. Strategic Management Journal, 30(8), 909-920. doi: 10.1002/smj.764

Morgan, Robert M, \& Hunt, Shelby D. (1994). The commitment-trust theory of relationship marketing. Jurnal of Marketing, 58(3), 20.

Mukhtar, Arshia, \& Mohsin Butt, Muhammad. (2012). Intention to choose Halal products: the role of religiosity. Journal of Islamic Marketing, 3(2), 108-120. doi: $10.1108 / 17590831211232519$

Nuraini. (2015). Fesyen Muslim Indonesia. WARTA EKSPOR. Kementrian Perdagangan Republik Indonesia., Ditjen PEN/WRT/31/IV/2015 edisi April.

Olavarrieta, Sergio, \& Friedmann, Roberto. (2008). Market orientation, knowledge-related resources and firm performance. Journal of Business Research, 61(6), 623-630. doi: 10.1016/j.jbusres.2007.06.037

Osakwe, Christian Nedu, Chovancova, Miloslava, \& Ogbonna, Benson U. (2016). Linking SMEs Profitability to Brand Orientation and Market-Sensing Capability: A Service Sector Evidence. Periodica Polytechnica Social and Management Sciences, 24(1), 3440. doi: 10.3311/PPso.8069

Racela, Olimpia C. (2014). Customer Orientation, Innovation Competencies, and Firm Performance: A Proposed Conceptual Model. Procedia - Social and Behavioral Sciences, 148, 16-23. doi: 10.1016/j.sbspro.2014.07.010

Singh, Ramendra, \& Koshy, Abraham. (2012). A new conceptualization of salesperson's customer orientation: Propositions and implications. Marketing Intelligence \& Planning, 30(1), 69-82. doi: 10.1108/02634501211193921

Soliman, Hisham Sayed. (2011). Customer Relationship Management and Its Relationship to the Marketing Performance. International Journal of Business and Social Science, Vol. 2(No. 10, June 2011).

Souiden, Nizar, \& Rani, Marzouki. (2015). Consumer attitudes and purchase intentions toward Islamic banks: the influence of religiosity. International Journal of Bank Marketing, 33(2), 143-161. doi: 10.1108/ijbm-10-2013-0115

Spiro, Rosann L., \& Weitz, BartonA. (1990).Adaptive Selling: Conceptualization, Measurement, and Nomological Validity Journal of Marketing Research, 27(1), 61-69.

Sterkens, Carl, \& Anthony, Francis-Vincent. (2008). A Comparative Study of Religiocentrism among Christian, Muslim and Hindu Students in Tamil Nadu, India. Journal of Empirical Theology, 21(1), 32-67. doi: 10.1163/092229308x310731 
Terho, Harri, Eggert, Andreas, Haas, Alexander, \& Ulaga, Wolfgang. (2015). How sales strategy translates into performance: The role of salesperson customer orientation and value-based selling. Industrial Marketing Management, 45, 12-21.

Wang, Yonggui, \& Feng, Hui. (2012). Customer relationship management capabilities. Measurement, antecedents and consequences. Management Decision, 50(1), 115-129. doi: $10.1108 / 00251741211194903$

Wang, Zhan, \& Kim, Hyun Gon. (2017). Can Social Media Marketing Improve Customer Relationship Capabilities and Firm Performance? Dynamic Capability Perspective. Journal of Interactive Marketing, 39, 15-26. doi: 10.1016/j.intmar.2017.02.004

Weitz, Barton A., Sujan, Harish, \& Sujan, Mita. (1986). Knowledge, Motivation, and Adaptive Behavior: A Frame-work for Improving - Selling Effectiveness Journal of Marketing 50(October), 174-191. 